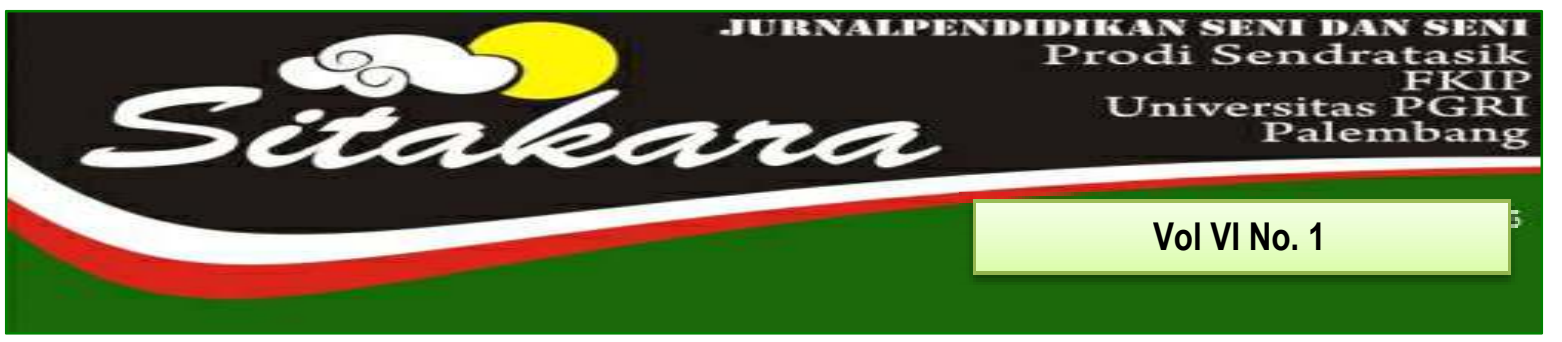

PERTUNJUKAN SOLIS MARIMBA DENGAN REPERTOAR THE VARIANTIONS ON THEME (FROM THE MALAY'S "PUCUK PISANG")

(Fery Herdianto)

BUKIT SIGUNTANG DALAM PENGEMBANGAN KONSEP RUANG KOREOGRAFI $\quad$ 13-26 LINGKUNGAN TARI

(Rully Rochayati, Eva Dina Chairunisa)

APLIKASI SIBELIUS SEBAGAI MEDIA PEMBELAJARAN DALAM MENULIS NOTASI MUSIK BERMAS

(Dedy Firmansyah \& Nugroho NAD)

PENGARUH MODEL PEMBELAJARAN EXPLICIT INSTRUCTION PADA 40-54 PEMBELAJARAN TARI DAERAH

(Treny Hera \& Efita Elvandari)

SIMBOLISASI ORNAMEN NAGA PADA PEMBATAS JALAN DI PALEMBANG (Decky Kunian \& A.Heryanto)

PENGARUH MODEL PEMBELAJARAN INSIDE-OUTSIDE-CIRCLE (IOC) TERHADAP WRITING SKILL DALAM TEKS MENULIS DRAMA DI SMP SETIA NEGARA PALEMBANG

(Sri Wahyu Indrawati \& Yuspar Uzer)

PEMANFAATAN TEKNOLOGI MULTIMEDIA DALAM PEMBELAJARAN MUSIK DI $79-87$ SMP N 1 PALEMBANG

(Novdaly Fillamenta \& Yuliza Aryani)

BENTUK PENYAJIAN ORKES GAMBUS SANGGAR MOZAIG PADA ACARA PERNIKAHAN ADAT ARAB PALEMBANG

(Auzy Madona Adoma)

PENINGKATAN KEMAMPUAN MEMBACA TEKS DRAMA DENGAN 100-111 MENGGUNAKAN METODE SPEED READING PADA PEMBELAJARAN BAHASA INDONESIA UNTUK SISWA SMPN 16 PALEMBANG (Wandiyo)

PELAKSANAAN EVALUASI PEMBELAJARAN SENI BUDAYA DI SMP 1 JEKULO 112-123 KUDUS PADA MASA PANDEMI COVID-19

M.Panji Wahyu Mukti \& Wahyu Lestari 
1. Naskah berbahasa Indonesia bertemakan Seni Budaya yang meliputi hasil penelitian pengajaran seni budaya, cabang seni, dan kebudayaan.

2. Naskah harus asli dan belum pernah dimuat dalam media lain. Naskah dapat berupa hasil penelitian perorangan atau kelompok.

3. Naskah ditulis dengan cara-cara yang sesuai dengan ketentuan penulisan artikel ilmiah menggunakan bahasa Indonesia yang baku, berupa ketikan, beserta soft line dalam CD-RW atau dengan mengirimkan email pada redaksi Jurnal SITARARA dengan alamat email: jurnalsitakarasendratasik@yahoo.com, spasi 1,5 jenis huruf Arrial Narrow ukuran 12, dengan panjang naskah antara 8-15 halaman pada kertas A4.

4. Artikel hasil penelitian memuat:

JUDUL

Nama Penulis

Abstrak

A. Pendahuluan

B. METODE PENELITIAN

C. HASIL DAN PEMBAHASAN

D. SIMPULAN
: XXX (HURUF KAPITAL)

: (disertai jabatan dan institusi)

: (Bahasa Indonesia yang memuat 100150 kata diikuti kata kunci, dengan jenis huruf Arrial Narrow dan ukuran huruf 11 spasi tunggal serta dicetak miring)

: (Memuat latar belakang masalah, tinjauan pustaka secara ringkas, masalah penelitian dan tujuan penelitian)

: (Berisi simpulan)

5. Artikel kajian konseptual memuat:

JUDUL

Nama Penulis

Abstrak

\section{: XXX (HURUF KAPITAL)}

: (disertai jabatan dan institusi)

: (Bahasa Indonesia yang memuat 100150 kata diikuti kata kunci, dengan jenis huruf Arrial Narrow dan ukuran huruf 11 serta dicetak miring)

PENDAHULUAN
: (Memuat latar belakang masalah, tinjauan pustaka secara ringkas, masalah penelitian dan tujuan penelitian) 
Sub Judul

Sub Judul

SIMPULAN

DAFTAR PUSTAKA
: Sesuai dengan kebutuhan (tanpa numbering)

: (Berisi simpulan dan saran)

: (Berisi pustaka yang dirujuk dalam uraian naskah

6. Referensi sumber dalam teks artikel ditulis dengan menggunakan side note, contoh: (Jalalluddin, 1991:79); (Taufik, 2005;350); (Hamid dan Madjid, 2011:43). Sementara penulisan daftar pustaka disusun dengan ketentuan. Nama Pengarang. Tahun Terbit. Judul (dicetak miring). Kota Terbit: Nama Penerbit. Contoh: Koentjaraningrat. 2010. Manusia dan Kebudayaan Di Indonesia. Jakarta: Djambatan.

Daftar pustaka hanya memuat pustaka/sumber yang dirujuk dalam uraian dan disusun menurut abjad, tanpa nomor urut.

7. Naskah yang dimuat akan disunting kembali oleh redaksi tanpa mengubah isinya.

8. Naskah yang ditolak (tidak bisa dimuat) akan dikirim kembali ke penulis dengan pemberitahuan tertulis dari redaksi atau alamat email.

9. Penulis yang naskahnya dimuat akan mendapatkan 1 (satu) majalah nomor yang bersangkutan.

10. Contact Person: Treny Hera (085357344704) dan Mainur (081373165553). 


\title{
PENGARUH MODEL PEMBELAJARAN EXPLICIT INSTRUCTION PADA PEMBELAJARAN TARI DAERAH SEBAGAI DASAR KETERAMPILAN MENARI TRADISI
}

\author{
Oleh: \\ Treny Hera ${ }^{1}$ \\ Efita Elvandari ${ }^{2}$ \\ (Dosen FKIP Universitas PGRI Palembang) \\ Email: trenyhera19@gmail.com
}

\begin{abstract}
ABSTRAK
Penelitian bertujuan untuk mengetahui adakah pengaruh model pembelajaran explicit instruction terhadap keterampilan menari tradisi pada pembelajaran tari daerah setempat. Metode yang digunakan dalam penelitian ini adalah penelitian deskriptif dengan pendekatan kuantitatif. Model Explicit Instruction merupakan suatu pendekatan mengajar yang berpengaruh terhadap keterampilan menari tradisi. Analisis data menunjukkan bahwa pada indikator sikap diperoleh jumlah nilai mahasiswa sebesar $90,66 \%$, pada indikator aktif sebesar $92,33 \%$, dan pada indikator respon persentase sebesar $74,5 \%$. Analisis datanya adalah kriteria penilaian aspek sikap, aktif, dan respon dalam kategori hasil belajar yaitu aktif dengan rata-rata 84,7. Penggunaan metode explicit instruction berpengaruh pada mahasiswa mempraktikkan materi tari dengan baik. Hal ini dibuktikan dengan tes praktik tari Tanggai dan Gending Sriwijaya, hasil penilaian tes praktik terlihat bahwa mahasiswa rata-rata sudah dapat mempraktikkan materi tari Gending Sriwijaya maka disimpulkan hasil belajar menari tradisi mencapai kategori belajar yaitu baik dengan rata-rata unjuk kerja mahasiswa mencapai 82,1.
\end{abstract}

Kata Kunci: Model Explicit Instruction, Keterampilan Menari.

\section{A. PENDAHULUAN}

$$
\text { Proses belajar mengajar }
$$

merupakan interaksi guru bersama

mahasiswa dengan menyediakan kondisi

belajar yang optimal. Kondisi belajar

yang optimal dapat dicapai jika guru

mampu mengatur mahasiswa dan

sarana pengajaran serta

mengendalikannya dalam suasana yang

menyenangkan untuk mencapai tujuan

pelajaran. Proses belajar mengajar merupakan suatu proses yang mengandung serangkai perbuatan guru dan mahasiswa atas dasar hubungan timbal balik yang berlangsung dalam situasi edukatif untuk mencapai tujuan tertentu. Interaksi atau hubungan timbal balik antara guru dan mahasiswa itu merupakan syarat utama bagi berlangsungnya proses belajar mengajar. Interaksi dalam peristiwa belajar mengajar mempunyai arti yang lebih luas, tidak sekedar hubungan 
antara guru dengan mahasiswa, tetapi berupa interaksi edukatif. Dalam hal ini bukan hannya penyampaian pesan berupa materi pelajaran, melainkan penanaman sikap dan nilai pada diri mahasiswa yang sedang belajar.

Berbicara mutu pendidikan dari hasil belajar, maka mutu pendidikan dapat dikatakan baik, apabila prestasi rata-rata mahasiswa telah mencapai target yang ditetapkan. Seiring dengan era globalisasi, dunia pendidikan dituntut agar dapat mempersiapkan mahasiswa yang mempunyai kemampuan menghapal, kemampuan berfikir kritis dan kreatif, keterampilan berkomunikasi dalam berkehidupan sosial untuk berpartisipasi secara utuh dalam kehidupan bermasyarakat dan mampu mengimbangi perkembangan dunia, khususnya dalam dunia seni dan hubungan sosial masyarakat yang berkaitan dengan tugas generasi sebagai generasi penerus kesenian.

Salah satu bentuk pembelajaran sebagai upaya melestarikan kesenian adalah mata kuliah Pembelajaran Tari Daerah Setempat yang merupakan suatu proses pembelajaran menari tradisi dengan gaya dan teknik yang sesuai berdasarkan bentuk teks tari yang telah disusun. Dalam pembelajaran tersebut terjadi interaksi antar individu mahasiswa yang memposisikan dirinya sebagai penari tradisi yang nantinya siap menjadi model demonstrasi pada saat mengajar di depan kelas. Keterampilan menari secara individu menjadi tujuan utama pembelajaran dikarenakan kompetensi yang harus dimiliki mahasiswa adalah mampu menari dan mampu mengajarkan.

Pembelajaran yang terjadi pada mahasiswa Program Studi Pendidikan Seni Pertunjukan FKIP Universitas PGRI Palembang merupakan proses yang universal yang terjadi di lingkungan pendidikan dan setiap saat secara terus menerus. Proses pembelajaran khususnya pada penelitian ini pada keterampilan menari tari daerah yang ditetapkan untuk memecahkan beragam masalah yang timbul yaitu berkembangnya tari tradisional tidak berdasarkan aturan pokok tari tradisional. Kekeliruan yang dialami oleh mahasiswa terhadap bentuk gerak tari tradisional menjadi permasalahan yang cukup serius, karena ini berpengaruh pada keberlangsungan dan lestarinya kesenian daerah. 
Pembelajaran tari daearah setempat harus diciptakan dan dirancang secara kreatif, yang memungkinkan terjadinya interaksi mandiri antara individu mahasiswa satu dengan mahasiswa lainnya. Dalam Pembelajaran Tari Daerah Setempat dilakukan secara individu juga berkelompok untuk menumbuhkan jiwa kerja sama dan menciptakan kondisi efektif dan efesien. Mata kuliah tari daerah modal utamanya adalah mahasiswa harus memiliki keterampilan juga keseriusan dalam memahami dan mempraktikan teknik gerak yang benar bukan asal bergerak saja. Berdasarkan pernyataan di atas masalah dalam penelitian sebagai berikut: 1) efektifitas Pengaruh model Pembelajaran Explicit Instruction Pada Pembelajaran Tari Daerah 2) Keterampilan Menari Tradisi Pada Mahasiswa UPGRI Palembang. Identifikasi masalah dalam penelitian sebagai berikut: 1) efektifitas Pengaruh model Pembelajaran Explicit Instruction Pada Pembelajaran Tari Daerah 2) Keterampilan Menari Tradisi Pada Mahasiswa UPGRI Palembang bisa terlatih dan tepat dalam teknik menari apabila dilakukan terbimbing dan dilatih terus menurus, tidak ada kemampuan seni yang autodidak, semua perlu proses, yaitu melalui pendidikan seni. Tujuan penelitian ini untuk mengetahui "adakah pengaruh Model Pembelajaran Explicit Instruction terhadap keterampilan menari tradisi pada pembelajaran Tari Daerah Setempat mahasiswa Program Studi Pendidikan Seni Pertunjukan FKIP UPGRI Palembang". Berikut kajian pustaka dalam penelitian ini:

- $\quad$ Hakikat Pembelajaran

Pembelajaran adalah kegiatan yang berhubungan proses belajar mengajar. Hal ini mengisyaratkan bahwa mahasiswa harus dijadikan sebagai pusat dari segala proses belajar mengajar. Kegiatan tersebut tidak hanya sekedar proses penyampaian materi saja, akan tetapi diselenggarakan untuk membentuk watak, peradaban, dan peningkatan mutu kehidupan peserta didik (Sanjaya, 2008).

Sedangkan pembelajaran sendiri berarti suatu kombinasi yang tersusun meliputi unsur-unsur manusiawi, material, fasilitas, perlengkapan, dan prosedur yang saling mempengaruhi mencapai tujuan pembelajaran (Isjoni, 2017). Pembelajaran adalah suatu sistem, artinya keseluruhan yang terdiri 
dari komponen-komponen yang berinteraksi antara satu dengan yang lainnya dan dengan keseluruhan itu sendiri untuk mencapai tujuan pembelajaran yang telah diterapkan sebelumnya, pengetahuan dan keterampilan dalam suatu bidang tertentu (Hamalik, 2008).

Prinsip yang pembelajaran yang dapat digunakan oleh guru adalah (1) Prinsip kebermaknaan; mahasiswa termotivasi untuk mempelajari hal-hal yang bermakna baginya, (2) Prasyarat; mahasiswa lebih suka mempelajari sesuatu yang baru jika dia memilki pengalaman prasyarat, (3) Model; mahasiswa lebih suka memperoleh tingkah laku baru bila disajikan dengan suatu model perilaku yang dapat diamati dan ditiru, (4) Komunikasi terbuka; mahasiswa lebih suka belajar bila penyajian ditata agar supaya pesanpesan guru terbuka terhadap pendapat mahasiswa, (5) Daya tarik; mahasiswa lebih suka belajar bila perhatiannya tertarik oleh penyajian yang menyenangkan dan menarik, (6) Aktif dalam latihan; mahasiswa lebih senang belajar bila dapat peran aktif dalam latihan atau praktik dalam upaya mencapai tujuan pembelajaran, (7)
Latihan yang terbagi; mahasiswa lebih suka belajar bila latihan-latihan dilaksanakan dalam jangka waktu pendek, (8) Keadaan yang menyenangkan; mahasiswa lebih suka belajar terus bila kondisi-kondisi pembelajaran menyenangkan baginya (Hamalik, 2008).

\section{- $\quad$ Pendidikan Seni Tari}

Peranan seni tari dalam proses pendidikan menjadi substansi seni tari sebagai intrumen pendidikan, khususnya pada era globalisasi saat ini (Hera: 2018). Tari merupakan ekspresi tubuh diwujudkan dalam rangkaian gerak kepala, tangan, badan, dan kaki yang digayakan berdasarkan unsur ruang, tenaga dan waktu. Suatu gerak bisa dikatakan gerak tari apabila gerak yang digayakan memiliki nilai estetis. Tari adalah gerak-gerak ritmis sebagian atau keseluruhan dari tubuh manusia yang terdiri dari pola individu atau berkelompok, yang disertai ekspresi dan ide tertentu (Elvandari, 2010).

Dari beberapa pendapat di atas, dapat disimpulkan bahwa tari merupakan gabungan dari keseluruhan gerak yang indah yang mengandung ruang, gerakan dalam waktu yang memilki tenaga baik 
secara ekspresi maupun gerak-gerak fisik dan psikis.

\section{- $\quad$ Fungsi Tari dalam Pendidikan}

Kehidupan manusia penuh dengan segala kegiatan, baik berupa kerja, belajar, atau kegiatan lainnya.. Tari sebagai salah satu media pendidikan untuk mengembangkan minat dan bakat seni yang akan membawa dampak yang positif bagi kreatifitas, tari pada hakekatnya merupakan ekspresi manusia yang diwujudkan dengan gerak yang lembut dan mempunyai aturanaturan tertentu yang dapat dipergunakan di dalam sikap dan tingkah laku seorang anak atau mahasiswa. "Tujuan pendidikan seni tari sebagai pola pengembang tingkah laku peserta didik membentuknya menjadi seorang penari agar mampu mengajarkan dan mencipta sebuah karya seni tari. Dalam telaah pembelajaran seni tari dalam pendidikan tidak hanya menuntut peserta diidk mampu untuk menari dengan baik, tetapi menuntut peserta didik mampu mencipta agar kelak menjadi guru yang kreatif mengikuti perkembangan zaman dalam ide kreatifnya sebagai sosok pendidik yang professional (Hera, 2018)"
Pengertian tentang fungsi tari kaitannya dengan keberadaan seni tari dalam masyarakat tidak hanya sekedar aktifitas kreatif, tetapi lebih mengarah pada kegunaan. Artinya keberadaan tari memiliki nilai guna dan hasil guna yang memberikan manfaat pada masyarakat, khususnya dalam mempertahankan kesinambungan kehidupan sosial. Fungsi tari yang berkembang sesuai dengan jamannya, yaitu tari berkembang dari bentuk yang ritual hingga bentuk-bentuk hiburan (Soedarsono, 2001).

Dari uraian di atas dapat disimpulkan bahwa fungsi tari adalah segala aktifitas manusia dalam seni tari memiliki nilai-nilai dan berguna pada masyarakat dalam mempertahankan kesinambungan dalam kehidupan masyarakat.

\section{- $\quad$ Tari Daerah}

\section{a) Tari Gending Sriwijaya}

Tari gending sriwijaya merupakan tari tradisional dari kota palembang hasil cipta karya lbu Sukainah Rozak dan Ibu Hj Tina Gong terinspirasi dari lagu gending sriwijaya oleh dahlan mahibat. Tari gending sriwijaya berfungsi sebagai tari sambut tamu agung tamu khusus dalam suatu 
acara formal. Tidak sembarang tamu yang boleh disambutdengan tarian ini dikarena sudah menjadi simbolis dan kesepakatan para seniman juga pemiliki kesenian. Materi pembelajaran daerah memilih materi pembelajaran tari Gending Sriwijaya secra tekstual dan kontekstualnya. Manfaat dari pembelajaran tari gending sriwijaya agar generasi muda memiliki tanggung jawab untuk melestarikan kesenian tradisional setempat. "Tari Gending Sriwijaya diresmikan menjadi tari sambut tamu kehormatan oleh Gubernur Sumatera Selatan H.Asnawi Mangku Alam tahun 1960an. Gending berasal dari bahasa Jawa yang artinya lagu, sri berarti "bercahaya" dan wijaya berarti "kemenangan". Tari Gending Sriwijaya merupakan tarian yang terinspirasi dari Lagu Gending Sriwijaya. Setelah lagu dan syair "Gending Sriwijaya" selesai pada tahun 1944, maka pemerintahan Jepang pada saat itu meminta agar diciptakan sebuah tarian untuk menyambut kedatangan para pembesar negara. Proses penciptaan tari Gending Sriwijaya dimulai tahun 1943 oleh Sukainah A. Rozak dan Tina Haji Gung menata gerak tari yang berkonsep tari palembang yang sudah ada (Hera, 2016)."

\section{b) Tari Tanggai \\ Fungsi utama tari Tanggai} Palembang sebagai sarana hiburan pribadi dan tontonan. Sedangkan fungsi sekunder tari Tanggai sebagai legitimasi pertanda acara dimulai dalam acara resmi maupun tidak resmi (Hera, 2020).

\section{- $\quad$ Model Pembelajaran Explicit Instruction}

Model ExplicitInstruction merupakan suatu pendekatan mengajar yang dapat membantu mahasiswa dalam mempelajari keterampilan dasar dan memperoleh informasi yang dapat diajarkan selangkah demi selangkah. Pendekatan mengajar ini sering disebut Model Pengajaran Langsung (Trianto, 2011).

Model Explicit Instruction adalah salah satu pendekatan mengajar yang dirancang khusus untuk menunjang proses belajar mahasiswa yang berkaitan dengan pengetahuan deklaratif dan pengetahuan prosedural yang terstruktur dengan baik yang dapat diajarkan dengan pola kegiatan yang bertahap, selangkah demi selangkah. Explicit dapat berbentuk "ceramah, demonstrasi, pelatihan atau praktik, dan kerja kelompok". 
Explicit Instruction digunakan untuk menyampaikan pelajaran yang ditransformasikan langsung oleh guru kepada mahasiswa (Nurdin, 2011). Dari berbagai kutipan di atas mengenai explicit instruction dapat disimpulkan bahwa model pengajaran langsung dirancang khusus untuk menunjang proses belajar mahasiswa yang berkaitan dengan baik, yang dapat diajarkan dengan pola kegiatan yang bertahap, selangkah demi selangkah. Pada model explicit instruction terdapat lima fase yang sangat penting. Guru mengawali pelajaran dengan penjelasan tentang tujuan dan latar belakang pembelajaran, serta mempersiapkan mahasiswa untuk menerima penjelasan guru.

Langkah-langkah model pembelajaran explicit instruction adalah sebagai berikut:

1) Menyampaian tujuan dan mempersiapkan mahasiswa

2) Mendemonstrasikan penetahuan dan keterampilan

3) Membimbing pelatihan

4) Mengecek pemahaman dan memberikan umpan balik

5) Memberikan latihan untuk latihan lanjutan (Nurdin M. , 2012)

\section{Evaluasi Pembelajaran}

Komponen utama sebagai alat ukur (evaluasi pembelajaran) untuk menilai kemampuan seni tari, ada tiga penilaian yaitu wiraga, wirama dan wirasa dan wirupa.

\section{a) Wiraga}

Wiraga adalah gerak anggota badan yang sesuai dengan sifat pembawaan dan penerapannya menurut keindahan sendiri (Sartono, 2007). Wiraga adalah penguasaan teknik gerak oleh penari. Unsur-unsur penilaian dalam wiraga adalah sebagai berikut:

a) Hafal penguasaan materi

b) Teknik gerak

c) Paduan koreografi

d) Komposisi ruangan.

\section{b) Wirama (Ukuran Waktu, Selaras)}

Wirama adalah ukuran waktu yang teratur dan menimbulkan rasa enak (selaras) karena wirama itu disebut ret atau jalannya rasa yang melalui gerak tari. Wirama merupakan penguasaan antara gerak dan irama musik tari yang selaras untuk mencapai keharmonisan ukuran gerak dan musik. Penguasaan dasar gerak tari dapat dikatakan 
sempurna atau lengkap dan harmonis, jika diungkapkan sudah betul-betul selaras dengan irama, atau ritmis dan empo dari setiap gerak, rangkaian gerak (ragam) serta ragam yang telah tersusun. Unsur-unsur penialian dalam wirama adalah sebagai berikut:

a) Ketepatan tempo yang selaras dengan iringan gerak penari

b) Kesuaian gerak cepat dan lambatnya gerakan dalam musik tari.

\section{c) Wirasa}

Wirasa aadalah semua gerak manusia tentu menggambarkan isi tujuan dan kemauan, jadi lahirnya rasa (wirasa) diwujudkan dengan pokok gerak yang sesuai (Sartono, 2007). Wirasa merupakan penghayatan penari saat memvisualkan gerakan tubuh. Penyesuaian rasa dan wujudnya gerak harus dapat dimengerti oleh yang melihat.

\section{B. METODE PENELITIAN}

Desain penelitian ini menggunakan pendekatan kuantitatif karena menggunakan angka, mulai dari pengumpulan data, penafsiran terhadap data tersebut, serta penampilan dari hasilnya (Suharsimi, 2005). Data dideskripsikan secara deduksi yang berangkat dari teori-teori umum, lalu dengan observasi untuk menguji validitas keberlakuan teori tersebut ditariklah kesimpulan. Kemudian dijabarkan secara deskriptif, karena hasilnya akan kami arahkan untuk mendiskripsikan data yang diperoleh dan untuk menjawab rumusan.

Desain penelitian ini merupakan suatu penelitian yang mempunyai tujuan untuk mendeskripsikan suatu fenomena, peristiwa, gejala, dan kejadian yang terjadi secara faktual, sistematis, melalui sumber data yang diperoleh dari hasil angket dan digunakan juga tes unjuk kerja keterampilan menari.

\section{HASIL PENELITIAN DAN PEMBAHASAN}

Berdasarkan hasil analisis data, diketahui bahwa pada indikator sikap diperoleh jumlah nilai mahasiswa sebesar 1.360 dan persentase sebesar $90,66 \%$ sedangkan pada indikator aktif diperoleh jumlah nilai mahasiswa sebesar 1.385 dengan persentase sebesar 92,33\%, dan pada indikator respon jumlah nilai sebesar 1.490 dan 
persentase sebesar 74,5\%. Analisis datanya adalah kriteria penilaian aspek sikap, aktif, dan respon dalam kategori hasil belajar yaitu aktif dengan rata-rata

84,7 .

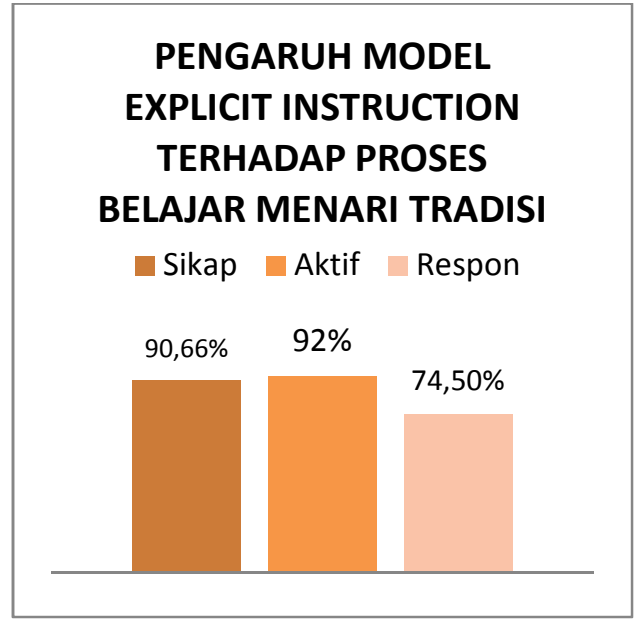

Tes uji kinerja dilakukan untuk mengetahui sejauh mana kemampuan mahasiswa dalam menerima pembelajaran dengan menggunakan model pembelajaran explicit instruction dan melakukan gerakan Tari Gending Sriwijaya. Komponen utama sebagai alat evaluasi pembelajaran untuk menilai kemampuan seni tari, yaitu 1) Wiraga adalah gerak anggota badan yang sesuai dengan sifat pembawaan dan penegterapannya menurut keindahan sendiri, 2) Wirama adalah ukuran waktu yang teratur dan menimbulkan rasa enak (selaras) karena wirama itu disebut ret atau jalannya rasa yang melalui gerak tari. 3) Semua gerak manusia tentu menggambarkan isi tujuan dan kemauan, jadi lahirnya rasa (wirasa) diwujudkan dengan pokok gerak yang sesuai dan yang 4) Harmoni (Wirupa) yaitu penilainnya digabungkan dari ketiga wiraga, Wirama, dan wirasa.

Pengumpulan data ini juga didapatkan dari hasil dokumentasi yang dilakukan selama melakukan penelitian, yang berupa foto-foto pada saat pembelajaran Tari Gending Sriwijaya oleh mahasiswa Jurusan Tari FKIP Program Studi Pendidikan Seni Pertunjukan UPGRI Palembang. Berikut disajikan hasil dokumentasi yang berupa foto-foto pembelajaran Tari Gending Sriwijaya.

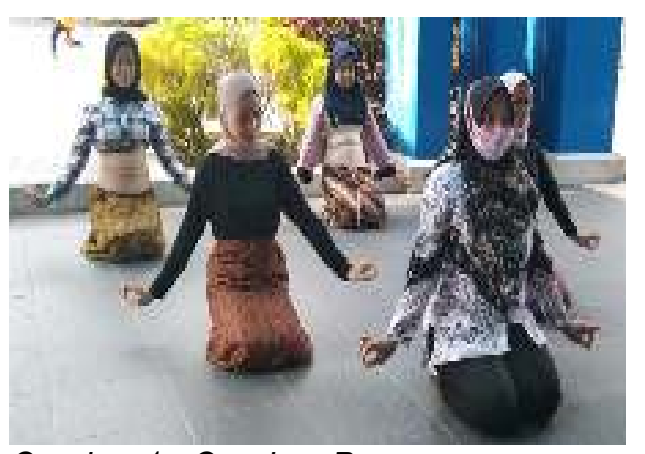

Gambar 1 : Gerakan Pemanasan

Peregangan Sebelum Pembelajaran

Setelah peregangan otot selesai selanjutnya, peneliti memperagakan beberapa gerakan tari Gending Sriwijaya kepada mahasiswa. 


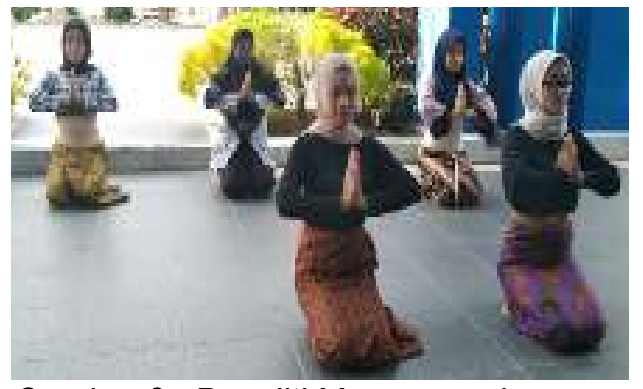

Gambar 2 : Peneliti Memperagakan Gerakan Hormat

Selama gerakan diperagakan oleh peneliti, mahasiswa memperhatikan dengan seksama agar dapat ditiru dan diperaktekkan ketika proses penjelasan oleh peneliti selesai.

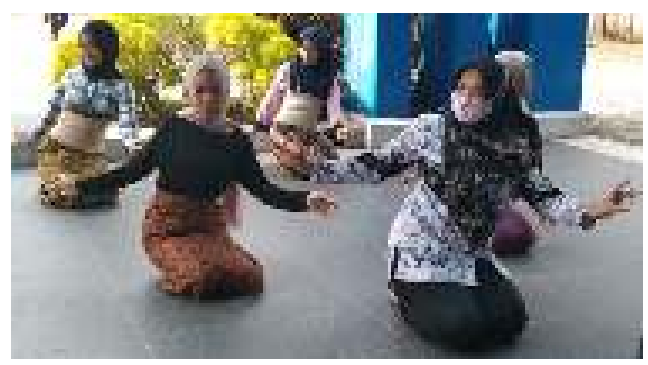

Gambar 3 : Peneliti Memperagakan Gerakan Pada Low Level

Selama proses gerakan, sesekali mahasiswa memperaktekkan apa yang diperagakan oleh peneliti. Gerakan ini dilakukan di awal dan di akhir tarian.

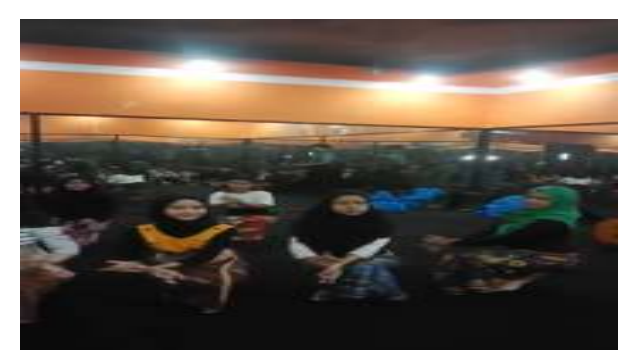

Gambar 4 : Peneliti Memperagakan Gerakan Masuk
Pelaksanaan pembelajaran menggunakan model explicit interaction diawali menyampaian tujuan pembelajaran dan mempersiapkan mahasiswa melalui pembelajaran gerak dasar tari tradisional Palembang. Pada tahap pelaksanaan pembelajaran awal yaitu pembelajaran secara terbimbing pada struktur awal tari.

Setelah instruksi explisit (explicit instruction) yang diberikan oleh peneliti berupa gerakan-gerakan yang ada pada tari Gending Sriwijaya, selanjutnya mahasiswa diajak untuk memperagakan gerakan yang telah disajikan.

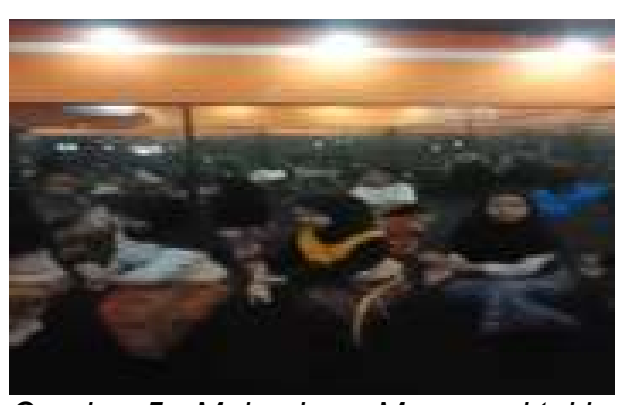

Gambar 5 : Mahasiswa Memperaktekkan Gerakan yang telah Disajikan Peneliti

Peneliti mendemonstrasikan pengetahuan dan keterampilan diikuti oleh semua mahasiswa secara bertahap. 


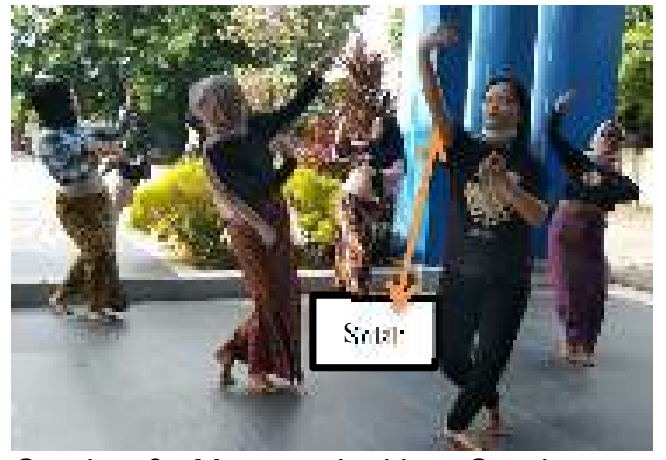

Gambar 6 : Memperaktekkan Gerak kecubung dengan posisi tangan salah

$$
\text { Selanjutnya mengecek }
$$

pemahaman mahasiswa dengan cara melihat hapalan gerak mahasiswa secara mandiri dan pada tahp ini akan memberikan umpan balik. Pneliti memberikan contoh gerakan yang benar agar setiap detail gerakan mahasiswa bisa dikontrol dan sesuai teknik gerak yang benar.

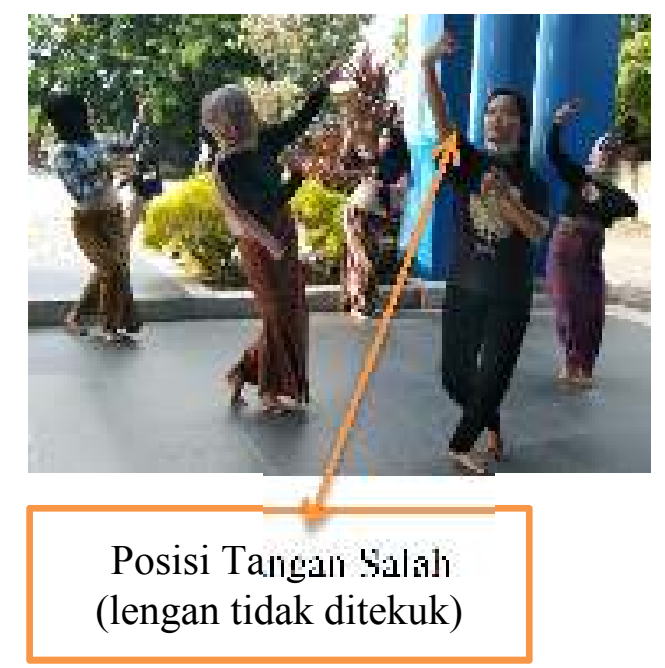

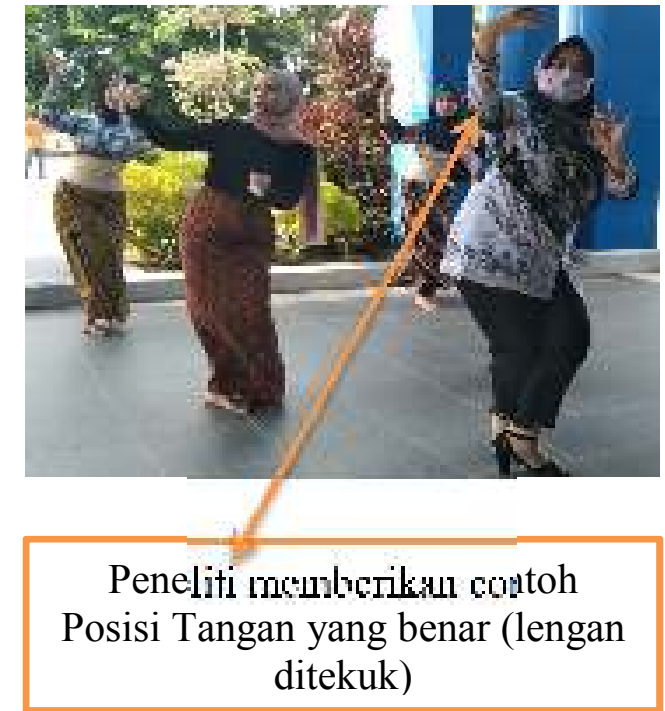

Gambar 7. Dosen memberikan bimbingan kepada mahasiswa dalam pembelajaran gerak tari. Memberikan umpan balik pada gerak tari.

$$
\text { Gerakan ditampilkan secara }
$$
berkelompok agar mahasiswa mampu meniru yang gerakan temannya sehingga terlihat seirama.

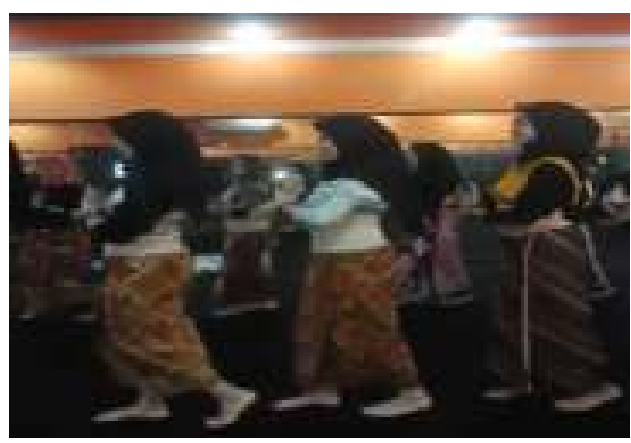

Gambar 8 : Mahasiswa Memperaktekkan Gerakan Secara Berkelompok

Peneliti Membimbing pelatihan dalam kontek pembelajaran struktur gerak tari. Setalah latihan terbimbing sudah dikuasi melalui evaluai hapalan. Selanjutnya 
Memberikan latihan untuk latihan lanjutan.

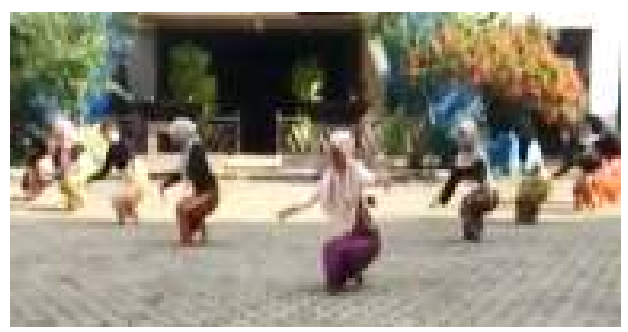

Gambar 9: Membimbing pelatihan dalam konteks pembelajaran struktur gerak awal (Gerak Sembah Atas).

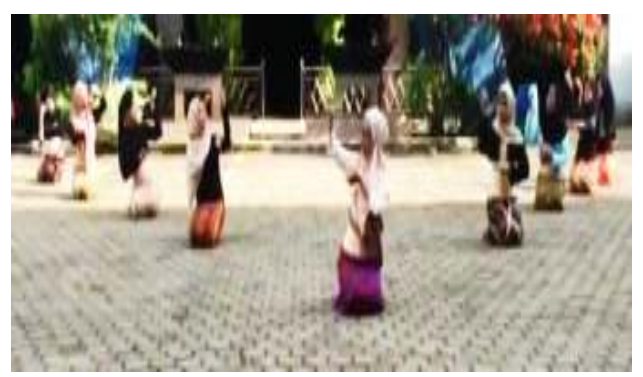

Gambar 10: Membimbing pelatihan dalam konteks pembelajaran struktur gerak inti (Gerak Berkumandang)

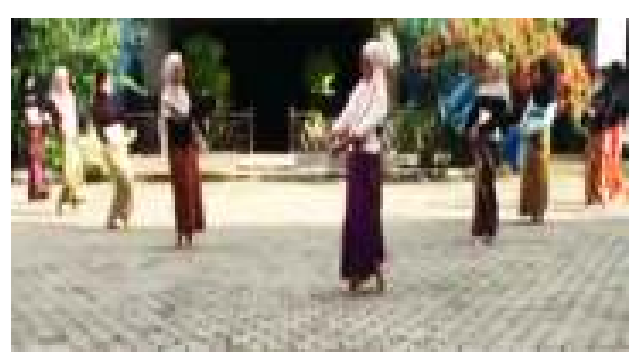

Gambar 11: Memberikan latihan untuk latihan lanjutan.

Dengan penentuan KKM 80 dalam tes praktik Tari Daerah (Tanggai dan Gending Sriwijaya), pada tabel hasil penilaian tes praktik di atas terlihat bahwa mahasiswa rata-rata sudah dapat melakukan/mempraktikkan materi Tari Gending Sriwijaya dengan kategori hasil belajar yaitu baik. Hal ini dapat dibuktikan pada penguasaan keterampilan wirama dengan jumlah nilai 1.390 pada persentase $92,66 \%$ dari hasil akhir tes artinya proses belajar menari dengan model explicit instruction berpengaruh signifikan terhadap keterampilan wirama mahasiswa, kemudian untuk keterampilan wiraga dengan jumlah nilai 1.660 pada persentase $83 \%$ seimbang dengan hasil wirama, dan wirasa dari hasil peneitian pada jumlah angka 1.055 yaitu hanya $70,33 \%$ hal ini dipengaruhi oleh pengalaman pentas menari daerah berbeda-beda dan belum banyak pengalaman berkeseniannya. Dengan rata-rata unjuk kerja pada keterampilan menari daerah mahasiswa mencapai nilai rata-rata 82,1 dari jumlah sampel sebanyak 50 mahasiswa.

Jika dilihat dari rata-rata keterampilan mahasiswa 82,1 maka data ini menunjukan bahwa keterampilan menari tradisi mahasiswa menggunakan model pembelajaran explicit instruction diukur melalui indeks yang menentukan kualitas tarinya, yang menyangkut bentuk gerak dan sikap secara berkesinambungan dan memenuhi standar kualitas penghayatan gerak. 


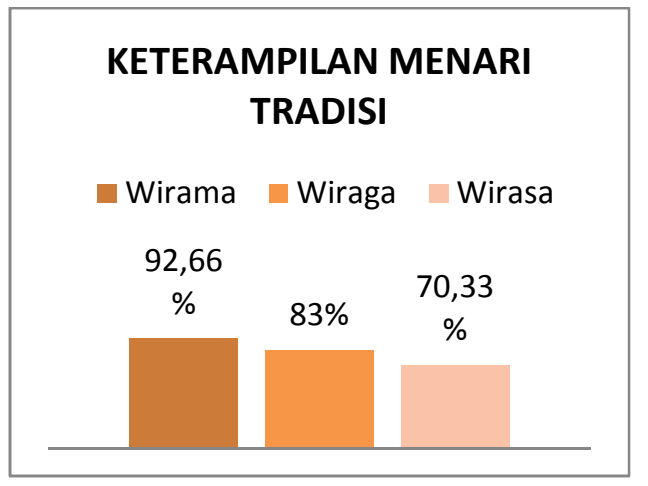

Penggunaan metode explicit instruction dalam pembelajaran Tari bahwa rata-rata mahasiswa sudah dapat melakukan/mempraktikkan materi Tari Gending Sriwijaya dengan baik.

Hal ini dapat dibuktikan dengan tes praktik Tari Daerah (Tanggai dan Gending Sriwijaya), pada tabel hasil penilaian tes praktik terlihat bahwa mahasiswa rata-rata sudah dapat melakukan/mempraktikkan materi Tari Gending Sriwijaya dengan kategori hasil belajar yaitu baik. Hal ini dapat dibuktikan dengan rata-rata unjuk kerja mahasiswa mencapai 82,1 dari jumlah sampel sebanyak 50 mahasiswa. Hal ini terjadi karena metode pembelajaran explicit instruction merupakan salah satu metode yang menekankan keaktifan mahasiswa dalam proses belajar mengajar, dimana guru hanya mempraktekkan tari Gending Sriwijaya beberapa kali yang selainjutnya diikuti oleh mahasiswa. Berdasarkan data yang telah diperoleh lalu dianalisis senda dengan pernyataan Dyna (2009:32), kelebihan model pembelajaran explicit instruction yaitu, 1) Dengan model pembelajaran langsung, peneliti mengendalikan isi materi dan urutan informasi yang diterima oleh mahasiswa sehingga dapat mempertahankan fokus mengenai apa yang harus dicapai oleh mahasiswa yaitu ketepatan dalam bergerak teknik yang baik dan benar, 2) Dapat diterapkan secara efektif dalam kelas yang besar maupun kecil. 3) digunakan untuk menekankan poinpoin penting atau kesulitan-kesulitan yang mungkin dihadapi mahasiswa sehingga hal-hal tersebut dapat diungkapkan, dalam penelitian ini fokus pada gerakan yang dianggap mahasiswa tingkat kesulitan penyamaan teknik gerak, 4) Dapat menjadi cara yang efektif untuk mengajarkan informasi dan pengetahuan faktual yang sangat terstruktur, khususnya pada tahapan pembelajaran struktur tari Daerah, 5) Merupakan cara yang paling efektif untuk mengajarkan konsep dan keterampilan-keterampilan yang eksplisit kepada mahasiswa yang berprestasi rendah karena di pada semester II dan V masih banyak terdapat mahasiswa yang 
memang kemampuan menarinya masih rendah, hal ini disebabkan oleh bakat menari yang tidak terlatih, 6) Dapat menjadi cara untuk menyampaikan informasi yang banyak dalam waktu yang relatif singkat yang dapat diakses secara setara oleh seluruh mahasiswa, 7) Memungkinkan ahli (peneliti) untuk menyampaikan ketertarikan pribadi mengenai mata pelajaran (melalui presentasi yang antusias) yang dapat merangsang ketertarikan dan dan antusiasme mahasiswa, khususnya pada mahasiswa yang minat tarinya masih sangat rendah, penguatan pada mahasiswa bahwa menari itu bukan hal yang autodidak melainkan melalui proses belajar yang terlatih dan tekun bukan hanya bergerak dan asal bergerak tidak menggunakan teknik bergerak yang baik dan benar.

\section{SIMPULAN}

Model explicit instruction merupakan suatu pendekatan mengajar yang berpengaruh terhadap keterampilan menari tradisi pada pembelajaran tari daerah setempat mahasiswa Program Studi Pendidikan Seni Pertunjukan FKIP
UPGRI Palembang. Melalui model pembelajaran Explicit Instruction membantu mahasiswa dalam mempelajari keterampilan menari tradisi dan memperoleh informasi yang dapat diajarkan khusus pada struktur tari selangkah demi selangkah karena dalam kompetensi dasar mahasiswa dituntut untuk memiliki keterampilan menari tradisi berdasarkan konsep 3W dalam pembelajaran tari daerah. Model ini membuat pengajar lebih bisa dan cenderung unruk mengontrol mahasiswa, karena pengajar ikut aktif dalam pelajaran dan membimbing mahasiswa di kelas daring. Mahasiswa juga dituntut aktif dalam pembelajaran secara individu maupun dalam kelompok. Dengan menggunakan model explicit instruction ini mahasiswa memiliki konsentrasi serius dalam mengikuti dan memperhatikan pembelajaran di dalam kelas khususnya daring. Berdasarkan data hasil analisis dapat disimpulkan bahwa pada indikator sikap diperoleh jumlah nilai mahasiswa sebesar 90,66\% sedangkan pada indikator aktif diperoleh jumlah nilai mahasiswa sebesar 92,33\%, dan pada indikator respon jumlah nilai sebesar $74,5 \%$. 


\section{DAFTAR PUSTAKA}

Dyna. (2009). Implementasi Pembelajaran Kooperatif Learning. Jakarta: Rineka Cipta.

Elvandari, E. (2010). Bahan ajar Sejarah Analisis Tari. Palembang: Universitas PGRI Palembang.

Hamalik, O. (2008). Proses Belajar Mengajar. Jakarta: Bumi Aksara.

Hera, T. (2016). Makna Gerak Tari Gending Sriwijaya Di Sanggar Dinda Bestari. SITAKARA, 48.

Hera, T. (2018, July). Aspek-aspek penciptaan tari dalam pendidikan. In Prosiding Seminar Nasional Program Pascasarjana Universitas PGRI Palembang (Vol. 5, No. 05).

Hera, T. (2020). Fungsi Tari Tanggai Palembang. Geter, 64-65.

Isjoni. (20017). Proses Pembelajaran dalam Kelas. Yogyakarta: Rineka Cipta.

Nurdin, M. (2012). Belajar dengan Pendekatan PAILKEM. Jakarta: Bumi Aksara.

Nurdin, U. d. (2011). Kooperatif Learning. Jakarta: Rineka Cipta.

Sanjaya. (2008). Strategi Pembelajaran Berorientasi Standar Proses Pendidikan. Jakarta: Prenada Media Group.

Sartono. (2007). Bahan Ajar Tari Daerah Setempat 1. Palembang: Universitas PGRI Palembang.

Soedarsono. (2001). Jawa dan Bali Dua Pusat Perkembangan Dramatari Tradisional di Indonesia. . Jakarta: Rineka Cipta.

Sudijono, A. (2008). Pengantar Evaluasi Pendidikan. Jakarta: PT Taja Grafindo Persada.

Sudjana. (2010). Metoda Statistika. Bandung: Tarsito.

Suharsimi, A. (2005). Prosedur Penelitian: Suatu Pendekatan Penelitian. Jakarta: Rineka Cipta.

Trianto. (2011). Model-Model Pembelajaran Inovatif Berorientasi Konstruktif. Jakarta: Prestasi Pustaka. 